\title{
Fyrretyve Fortællinger af Fædrelandets Historie
}

\section{Omkring et berømt værks tilblivelse}

\section{Af Harald Jorgensen}

Den 16. september 1882 satte historikeren A. D. Jørgensen sig til sit skrivebord og afsendte følgende linier til sin faderlige ven og velgører, stiftamtmand Th. A. J. Regenburg i Skanderborg: "Højvelbårne hr. stiftamtmand. Hermed tillader jeg mig at sende Dem et lille opus, som idag ser solens lys for første gang. Det er skrevet efter opfordring af brygger Jacobsen og er trykt i 10.000 eksemplarer til uddeling i Nordslesvig foruden 5.000 , som skal sælges her i kongeriget af folkelæsningsselskabet. Nogen interesse vil det vel nok have for Dem af denne grund, og måske tillige, fordi det indeholder resultaterne af mine studier af Slesvigs historie, så vidt jeg hidtil er kommen med dem «. ${ }^{1}$ Det lille opus, som omtales i brevet, var de 40 fortællinger af fædrelandets historie, som altså i år kan fejre sin 100-årsdag.

Der skal ikke ved denne lejlighed og på dette sted tegnes et udførligt portræt af sønderjyden og historikeren A. D. Jørgensen (1840-97). Det er sket adskillige gange tidligere. ${ }^{2}$ Derimod kan det være på sin plads at benytte 100-årsdagen til at betragte baggrunden for værkets tilblivelse dels i forhold til den nationalpolitiske udvikling i Nordslesvig i årene frem til 1881, dels på baggrund af forfatterens hidtidige litterære virksomhed.

A. D. Jørgensen var lærer i Flensborg, da krigen brød ud. Han ønskede imidlertid ikke at gå i de nye magthaveres tjeneste, og i marts 1864 tog han toget fra Flensborg til Ha mborg og videre til Lübeck, hvorfra turen gik videre med skib til Malmö og København. I de følgende år ernærede han sig ved at give undervisning, og i 1869 fik han en assistentstilling ved Kongerigets arkiv, hvor han relativt hurtigt avancerede til fuldmægtig med en årsgage på 2.000 kr.

Efter ankomsten til København genoptog han ungdomstidens frie studier. Under indtryk af begivenhederne 1864 blev han klar over sit fremtidsmål. Han ville være historiker, og hans hovedopgave skulle være at udforske "grunden til Danmarks ulykke «. ${ }^{3}$ Studierne hindrede ham imidlertid ikke i stadig at følge udviklingen i Nordslesvig. Allerede i vinteren $1864-65$ havde han lejlighed til at gaste Nordslesvig, idet han sammen med den senere generalauditør $\mathbf{H}$. Steffensen skulle indsamle underskrifter på et planlagt bønskrift til kejser Napoleon III. Også i de følgende år kom han ofte til 


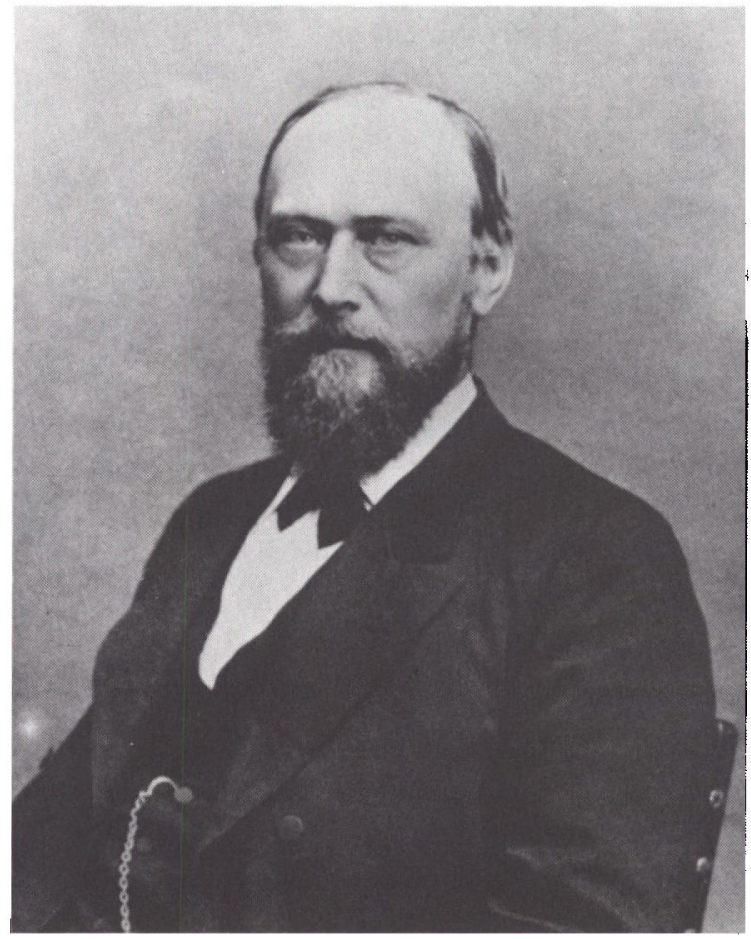

Fuldmagtig i Kongerigets Arkiv A. D. Jorgensen. Fra l. januar 1883 udnavntes han til gehejmearkivar, og i 1889 blev han rigsarkivar. Han dede 1897.

Gråsten på besøg hos faderen, der levede indtil 1883. I 1866 var han medstifter af en forening, kaldet Sønderjysk Samfund, der bestod af landflygtige sønderjyder, der havde taget ophold i København. Han blev et meget aktivt medlem af denne forening, som mødtes hver torsdag aften til foredrag og oplæsning. Det var i denne kreds, at han for første gang optrådte som foredragsholder. I foreningen traf han desuden en række personer, der gennem et langt liv havde virket i den sønderjyske sags tjeneste, bl.a. redaktør Peter Kr. Koch, professor Chr. Flor, forfatteren Frederik Barfod og pastor H. W. Hertel. Foreningen eksisterede dog kun en kortere årrække.

I 1866, da rygterne begyndte at svirre omkring Pragfredens $\S 5$, besluttedes det $\mathrm{i}$ København, at der påny skulle tilvejebringes en adresse til støtte for udførelsen af løfteparagraffen. På ny drog Jørgensen og Steffensen afsted for i Nordslesvig at indsamle de fornødne navne. Der kom imidlertid ikke noget ud af adressen, og man besluttede $i$ stedet for at sende en deputation fra Nordslesvig til kong Wilhelm i Berlin med anmodning om at gennemfere den lovede afstemning. Deputationen, der lededes af den senere nordslesvigske politiker Nic. Ahlmann, opnåede dog ikke foretræde for kongen. 


\section{Træk af den nationalpolitiske udvikling i Nordslesvig indtil 1881}

Indtil slutningen af 1870 'erne levede den nordslesvigske befolkning $\mathrm{i}$ håbet om en snarlig genforening med moderlandet. ${ }^{4}$ Der førtes diplomatiske forhandlinger herom mellem Danmark og Preussen, men de krav, der stilledes fra preussisk side, var så vidtgående og tilbudet om afståelse af slesvigsk område så begrænset, at der ikke kom noget positivt resultat ud heraf. Det er imidlertid et spørgsmål, om der fra ansvarlig preussisk side nogensinde har været et alvorligt ment ønske om at flytte grænsen mod syd. I hvert fald bortvejredes et sådant ønske efter udfaldet af krigen med Frankrig i 1870-71 og oprettelsen af det tyske kejserrige. Fra tid til anden udtalte preussiske embedsmænd ved deres ansættelse i Nordslesvig, at Tyskland umuligt kunne opgive, hvad man med fuld ret besad $i$ henhold til Wienertraktaten af 1864 og Pragerfreden af 1866 . De politiske repræsentanter for den danske befolkning benyttede ganske vist enhver anledning til at minde Preussen om det givne lofte i Pragerfreden om en afstemning i de nordlige distrikter af Slesvig ( $(5)$, men uden resultat. I 1878 fik Bismarck den østrigske regering til i en traktat af 11 . oktober 1878 at sætte den lovede afstemning ud af kraft, og 4. februar 1879 blev der i en kort meddelelse givet offentligheden besked herom. I den danske offentlighed, såvel i Nordslesvig som i kongeriget, hævdedes imidlertid, at Nordslesvig uanset ophævelsen af $\S 5$, fortsat havde en national og moralsk ret til genforening med moderlandet.

I kraft af Pragerfreden af 1866 indlemmedes Sønderjylland i Preussen og sammen med Holsten udgjorde det en preussisk provins under ledelse af en overpræsident. Regeringen i Berlin havde ønsket, at denne provins i lighed med andre skulle opdeles i to regeringsdistrikter (Slesvig og Holsten), men den preussiske landdag modsatte sig dette, og der oprettedes ét regeringsdistrikt, hvis hovedsæde blev Slesvig by. Ved siden af den højeste provinsforvaltning fandtes en folkevalgt provinslanddag med rådgivende myndighed med hensyn til de love, som regeringen i Berlin forelagde den til udtalelse, og besluttende i mere lokale spørgsmål.

Regeringen i Berlin indførte omgående preussisk lovgivning med hensyn til retsvæsen og lokalforvaltning. Der gennemførtes nu en adskillelse mellem den dømmende og udøvende magt, og de fra gammel tid eksisterende indviklede jurisdiktionsforhold forenkledes, hvilket også modtoges med tilfredshed af lokalbefolkningen.

En konsekvens var, at tysk uddannede og tyskorienterede embedsmænd lidt efter lidt rykkede ind i de nye retslige og administrative embeder. Meget 
af det nye måtte virke fremmedartet på befolkningen, idet der kun blev taget ringe hensyn til de eksisterende lokale forhold. Der var dog endnu ikke tale om en konsekvent udryddelse af dansk sprog i forvaltning og i retssalene. I udpræget danske områder var såvel rets- som forvaltningssproget blandet. Den enkelte borger kunne selv bestemme, i hvilket sprog han ville henvende sig til myndighederne. At disse til gengæld søgte at fremme anvendelsen af det tyske sprog er åbenbart. Bedst lykkedes det $\mathrm{i}$ købstæderne og $\mathrm{i}$ landsoverretten. Når reaktionen fra dansk side indtil videre blev begrænset, hænger det naturligvis sammen med, at man stadig regnede med, at genforeningens dag ikke var fjern.

En kraftig reaktion opstod imidlertid, da regeringen indførte tvungen og treårig militærtjeneste for alle unge mænd, der havde nået 20 -årsgrænsen. Adskillige ønskede ikke at underkaste sig denne militærtjeneste, og en betydelig udvandring fandt sted til kongeriget og til Amerika. En del af de til kongeriget udvandrede opterede for Danmark i henhold til Wienertraktatens $\S 19$, hvilket havde til følge, at de kunne bevare deres faste ejendom i Sønderjylland og tage ophold her. Myndighederne forbeholdt sig imidlertid ret til at udvise dem, hvis de viste statsfjendtlig virksomhed. Adskillige unge havde imidlertid ikke fåt afgivet deres optionsbegæring i rette tid eller havde først afgivet den, efter at de havde modtaget indkaldelsesordre. Det vakte imidlertid almindelig tilfredshed, at det ved Åbenråkonventionen af 1872 blev aftalt, at samtlige optanter fremtidig skulle behandles ens, altså som danske statsborgere, og have tilladelse til at opholde sig i Nordslesvig, "forsåvidt og sålænge de ikke tager del i agitatoriske bestræbelser eller på anden måde falder til besvær». Som "danske statsborgere" havde de imidlertid hverken politisk eller kommunal stemmeret, og dette forklarer bl.a. den nedgang $\mathrm{i}$ antallet af danske stemmer ved valgene til rigsdag, landdag og kommunale forsamlinger, der kunne konstateres i løbet af 1870 'erne.

I de første år efter indlemmelsen i Preussen havde der været stilstand på skolefronten, og myndighederne havde tilmed tilladt oprettelsen af private danske real- og højskoler. Senere ændrede man holdning, og flere af disse skoler blev lukket. Efter 1870 satte man desuden en bevidst fortyskning ind overfor den almindelige folkeskole. Der var her og der udfoldet bestræbelser for at indføre tysk undervisningssprog, men disse forsøg var gennemgående blevet afvist. Den 26. august 1871 indførtes imidlertid en almindelig bestemmelse om, at der med det tredje skoleårs begyndelse skulle indføres 6 ugentlige undervisningstimer i tysk, som kunne forøges til 8 à 10 timer, hvis forældrekredsen ønskede det. Officielt motiveredes denne nye ordre med, at det var af interesse for den opvoksende ungdom at kende tysk, når de til sin 
tid skulle indtage deres plads i samfundet. Myndighedernes krav vakte imidlertid megen uvilje i danske kredse, og denne kom tydeligt til orde i den lokale danske presse. Man reagerede ligeledes mod indførelse af tyske skolebøger. I mange sogne fik skoleinstruksen ingen større betydning, da den stedlige lærer ikke var istand til at opfylde kravene om tysk sprogundervisning. Præsterne fik derfor besked om at medvirke til lærernes uddannelse i det tyske sprog. Myndighederne forsøgte forskellige steder, hvor forældreinteressen for den danske skole ikke var særlig stor eller aktiv, med udgangspunkt $\mathrm{i}$ cirkulæret af 1871 , ikke alene at udvide tyskundervisningen, men også lidt efter lidt at indføre tysk undervisningssprog. Dette lykkedes f.eks. i en række sogne i Slogs herred.

I 1876 havde den tyske rigsdag vedtaget en lov om tysk forvaltningssprog $i$ de ikke-tysktalende provinser. Ved en kgl. kundgørelse af 28 . august 1876 anerkendtes visse overgangsbestemmelser for Nordslesvig, idet man endnu i 5 år tillod Haderslev kredsdag at have dansk forhandlingssprog. Man pålagde også en 20-årsfrist for udskiftning af dansktalende kommuneforstandere med tyske. I Åbenrå og Sønderborg kredse blev det straks forbudt at anvende dansk, og også ved domstolene blev det tyske sprog enerådende.

Loven om forvaltningssproget smittede af på sproget i skolerne. Gennem 1870'erne havde man fortsat sine bestræbelser for at fortyske skolen, og man havde tilmed inddraget bornene i fortyskningsprocessen ved at opfordre dem til at tale tysk med forældre og kammerater. Større betydning havde det, at man ved indførelse af de såkaldte kredsskoleinspektører øgede kontrollen med præster og lærere. Større resultater var dog ikke opnået, og i 1878 gjorde man derfor et nyt fremstød, idet man forøgede tyskundervisningen i øverste klasse til 12 ugentlige timer og forlangte, at undervisningen $\mathrm{i}$ historie, geografi, hovedregning, sang og gymnastik skulle foregå på tysk og udenfor de ovennævnte 12 timer. Fortyskningen af skolen havde gjort et betydeligt skridt fremad.

Ved Preussens annektion af Sønderjylland var flertallet af folkeskolelærerne i Nordslesvig af slesvigsk herkomst og dansksindede, og i modsætning til sognepræsterne forblev flertallet $i$ deres stillinger. I 1867 forlangte regeringen, at lærerne skulle aflægge troskabsed til den preussiske konge. Nægtede de det, kunne de afskediges. En del lærere aflagde eden og kunne således forblive på deres poster, hvilket havde en ikke ringe national betydning, da de, støttet af den stedlige befolkning, i større eller mindre grad kunne sabotere den tyske skolepolitik. Også præsterne blev afkrævet ed, og flere af dem afslog det, hvorefter de blev afskediget. Da man i 1870 pålagde dem i kirkebønnen at bede for tysk sejr, var der flere, der nægtede, og en afskedigelse blev følgen. Da adskillige danske præster allerede i 1864 var 
blevet tvunget bort fra deres embeder, betød det, at den nordslesvigske præstestand $\mathrm{i}$ vid udstrækning afløstes af tysksindede præster.

Der var begrænsede muligheder for den dansksindede befolkning for direkte at modsatte sig fortyskningen af landsdelen; men man behøvede ikke at forholde sig tavs. I 1867 fik man en udmærket lejlighed til at demonstrere sin danskhed for offentligheden. Der blev udskrevet valg til den nordtyske rigsdag, og resultatet viste, at der var dansk flertal indtil en linje syd om Flensborg og over til Tønder og Højer. Valgresultatet var en ubehagelig overraskelse for myndighederne, og man sørgede også omgående for at få valgkredsene omlagt på en sådan måde, at der for fremtiden kun kunne vælges én dansk rigsdagsmand. Det blev da hans opgave ene mand at hævde de danske synpunkter på rigsdagen. Der skulle også vælges repræsentanter til den preussiske landdag. For at kunne deltage i landdagens møder, skulle man imidlertid aflægge ed på den preussiske forfatning. De danske repræsentanter ønskede imidlertid kun af aflægge eden med det forbehold, at $\S 5$ blev opfyldt. Det nægtede landdagen, og de danske repræsentanter kunne således ikke foreløbig møde og indtage deres pladser. Endelig havde man mulighed for at vælge repræsentanter til provinslanddagen og de forskellige kredsdage, men kun på ret begrænsede og lokale områder kunne man øve en vis dansk indflydelse.

Det bedste forsvar for danske rettigheder i denne periode blev ført af de dansksindede aviser. Flere gamle danske blade var forsvundet $\mathrm{i}$ og med krigen i 1864, men da den preussiske presselov blev indført i Nordslesvig i 1867 , blev der nye muligheder for en dansksindet presse. Det gamle førende danske presseorgan Dannevirke genopstod i Haderslev med den tidligere borgmester $\mathrm{H}$. R. Hiort-Lorenzen som redaktør. I 1877 blev han tvunget til at forlade landsdelen. I 1868 oprettedes det danske blad Dybbøl-Posten i Sønderborg, og året efter grundlagdes det blad, der senere skulle få en så stor betydning for landsdelens danskhed, nemlig Flensborg Avis. Udgiver og redaktør var indtil videre den senere rigsdagsmand Gustav Johannsen. De danske bladledere og journalister måtte udvise stor behændighed for at undgå beslaglæggelser og anklage, og flere af dem lærte tyske fængsler at kende, ligesom de måtte udrede betydelige bøder. Selv om den tyske censur vagtsomt fulgte den danske presse, var de danske aviser et virksomt middel $i$ nationalitetskampen.

På dette tidlige tidspunkt eksisterede der ingen større samlende organisationer eller foreninger. Man mødtes i små lokale kredse, bl.a. til dyrskuer o.lign,, og også disse foranstaltninger var under nøje opsigt fra politimyndighedernes side. Det samme gjaldt kontakten med kongeriget. Der lagdes adskillige hindringer $\mathrm{i}$ vejen for større samlede udflugter, ligesom man 
heller ikke tillod sådanne besøg fra den anden side af grænsen. Nordslesvig skulle om muligt afskæres fra sine gamle og intime forbindelser med kongeriget både på det økonomiske og åndelige område. Dette betød, at danskhedens fremtid i første række afhang af sammenholdet indenfor de små og isolerede samfund, og at hjemmenes holdning fik en aldeles afgørende betydning.

Da håbet om en snarlig genforening brast i 1879, var man imidlertid klar over, at nationalitetskampen måtte lægges an på en anden måde og gøres mere langsigtet. Den golde protestpolitik overfor landdagen kunne ikke fortsætte, og man måtte også se med nye øjne på spørgsmålet om den mandlige ungdoms udskrivning til preussiske soldater. Herom var meningerne i landsdelen meget splittede, og der forestod langvarige og smertefulde debatter, inden man nåede frem til en ny politik.

Man måtte også mere aktivt imødegå den fremadskridende fortyskning inden for samfundet og navnlig inden for skolen. Der måtte endvidere gøres en indsats for at bryde isolationen mellem kongeriget og Nordslesvig. Der måtte skabes bedre muligheder for, at den opvoksende slægt kunne få kendskab til dansk samfundsliv og kultur i alle dens afskygninger, og hjemmene måtte styrkes $\mathrm{i}$ deres bestrabelser for at udvikle børnenes kundskaber i dansk. Et nyttigt middel i denne sammenhæng var oprettelsen af danske folkebiblioteker og en videre udbredelse af danske bøger. I efteråret 1880 besluttede en kreds af fremtrædende danske nordslesvigere, bl.a. Gustav Johannsen, tobaksfabrikant J. P. Junggreen i Åbenrå og kollaborator C. F. Monrad i Flensborg at oprette "Foreningen til det danske sprogs bevarelse i Nordslesvig ", i daglig tale kaldet Sprogforeningen. Dens ledere havde nære kontakter med sønderjysk interesserede kredse i kongeriget, og disse sørgede for, at der blev insamlet de fornødne penge til indkøb af lødig dansk litteratur til udbredelse i Nordslesvig. Blandt de bøger, der gennem Sprogforeningen fandt vejen til de tusind danske hjem omkring $\mathrm{i}$ landsdelen, var også A. D. Jørgensens $" 40$ fortællinger af fædrelandets historie».

\section{A. D. Jørgensens historiske forfatterskab indtil 1881}

A. D. Jørgensen debuterede som historiker i 1868. Han var da 28 år gammel. Hans første afhandling drejede sig om de sønderjyske strandfrisers foregivne selvstændighed i middelalderen. ${ }^{5}$ Fra samme år stammer endvidere en artikel om de Hamborgske ærkebispers forsøg på at generhverve primatet over den nordiske kirke, og endelig offentliggjorde han en artikel om Danevirke. Også 
i de følgende år udkom adskillige afhandlinger omhandlende vidt forskellige emner, men for størsteparten hentet fra vor tidligste historie og fra middelalderen. Også norske emner fra samme tidlige periode blev skrevet og udgivet. Ved flere lejligheder tog han særlige sønderjyske problemer op til drøftelse. Han studerede Flensborgs og Åbenrås ældste historie og beskæftigede sig desuden med Slesvigs ældste befæstninger og senere med byens gamle stadsret. Om de her nævnte artikler gælder det, at forfatteren byggede sin fremstilling på de originale historiske kilder, der på det tidspunkt var kendt og udgivet.

En del af de ældste artikler samledes $i$ en selvstændig publikation, der udkom på Gyldendals forlag i 1871 under titlen "Bidrag til Nordens historie i middelalderen «, en lille bog på 288 sider. Artiklerne var grupperet i 3 afdelinger; artikler om Nordens sydgrænse, om danske folkeviser og om nordisk historieskrivning i den ældre middelalder (Saxo). Forfatteren havde utvivlsomt tænkt sig ved en senere lejlighed at udgive en ny samling afhandlinger, men denne tanke blev aldrig udført.

Fra forordet, der er dateret september 1871, skal bringes følgende citat: "Skønt hver af disse afhandlinger antages at kunne gøre krav på fuld videnskabelighed ved både at føre til selvstændige resultater og at tilstræbe deres begrundelse ad videnskabelig vej, så er de dog alle affattede med det mål for øje at være tilgængelige for enhver dannet læser, uden kendskab til de benyttede kilders sprog, og forfatteren vil anse det for den største personlige tilfredsstillelse, om sådanne læsere kunne føle sig tiltalt af fremstillingen «. Autodidakten A. D. Jørgensen var allerede på dette meget tidlige stadium af sin forfatterbane klar over, at faghistorikerne muligvis ville rynke på næsen af hans arbejde. På den anden side fandt han trøst i det håb, at den almindelige læser ville finde behag $i$ hans fremstilling. Dette håb skulle nu som senere til fulde gå i opfyldelse.

Hans daglige arbejdsplads var i de første år i universitetsbibliotekets nye bygning på Frue Plads. Her gjorde han bekendtskab med bibliotekarerne $\mathrm{H}$. Gundorp og S. Birket-Smith, som tilskyndede ham til at få de udarbejdede afhandlinger trykt. De satte ham bl.a. i forbindelse med kirkehistorikeren $\mathrm{H}$. F. Rørdam, der var medlem af bestyrelsen af det i 1848 stiftede Selskab for dansk Kirkehistorie, og som fra 1857 redigerede de af selskabet udgivne Kirkehistoriske Samlinger. I dette tidsskrift fik Jørgensen sin første kirkehistoriske afhandling om de ha mborgske ærkebisper offentliggjort. Også i de følgende år optog Rørdam andre af Jørgensens kirkehistoriske afhandlinger i sit tidsskrift. Rørdam havde i årene 1860-64 virket som sognepræst i Satrup i Angel. I marts 1864 var han blevet afsat af den østrigsk-preussiske civilregering og var ligesom Jørgensen draget til København. 


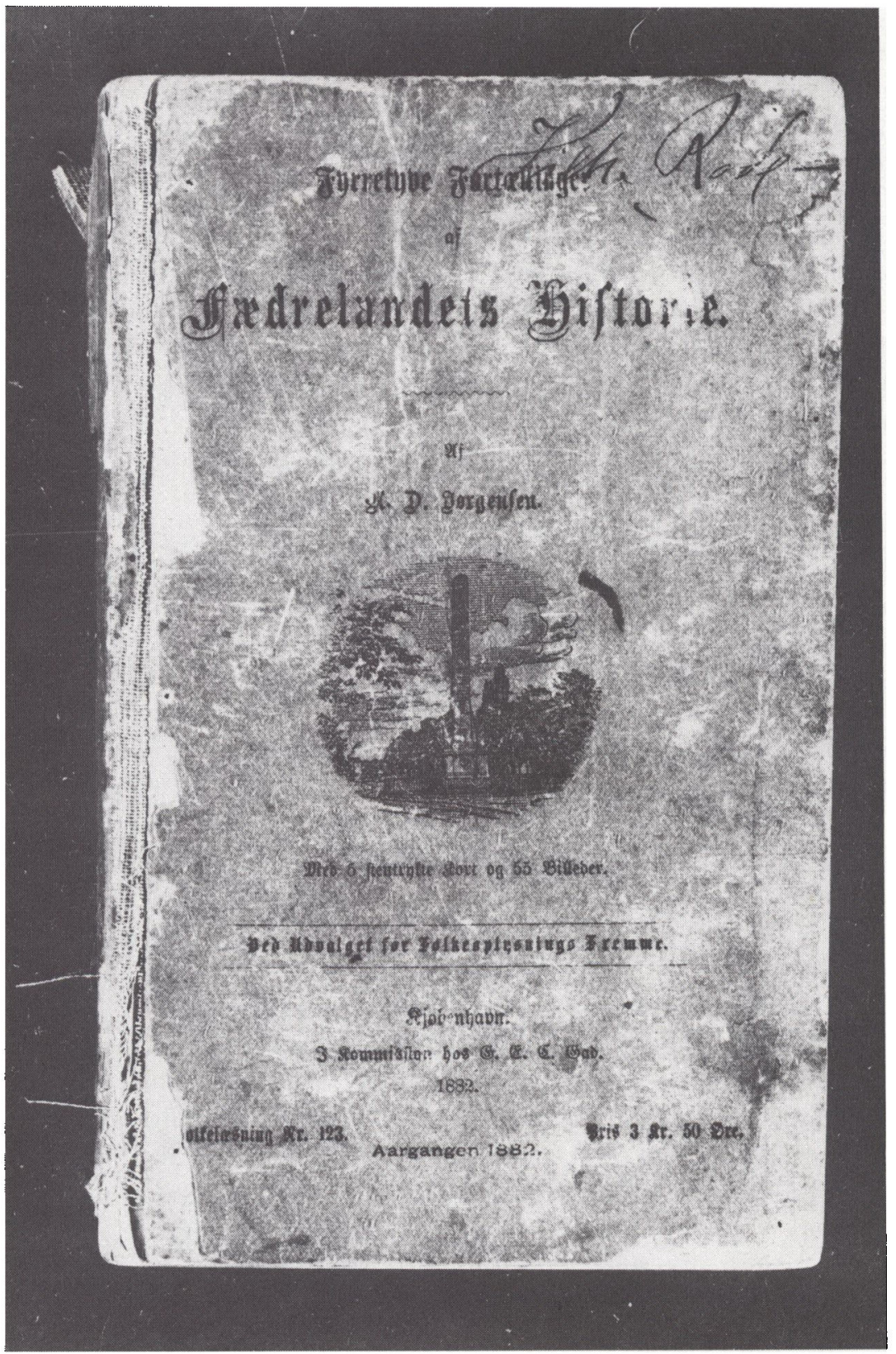

Originalomslag i pap til 1. udgave af Fyrretyve Fortallinger af Fadrelandets Historie. Pris 3 kr. 50 ore. 
Rørdam skaffede endvidere Jørgensen $\mathrm{i}$ forbindelse med en anden fordreven sønderjyde, nemlig arkæologen Conrad Engelhardt, som tidligere havde virket i Flensborg. Engelhardt havde fra 1868 overtaget redaktionen af Årbøger for nordisk Oldkyndighed og Historie, og i årene 1868-80 fik Jørgensen optaget ikke mindre end 8 ret omfangsrige artikler i dette tidsskrift.

Endnu en tidsskriftsredaktør fik den unge Jørgensen kontakt med, nemlig forfatteren Rudolf Schmidt. Også her var det Birket-Smith, der formidlede kontakten. Rudolf Schmidt var digter og oversætter og havde ligeledes skrevet små skuespil, der dog aldrig slog igennem. Han var desuden filosofisk interesseret og stod professor Rasmus Nielsen meget nær. Endelig virkede han som kritiker og essayist. Sammen med Rasmus Nielsen grundlagde han $\mathrm{i}$ 1869 tidsskriftet For Idé og Virkelighed med forbillede i det kendte franske kulturtidsskrift Revue des deux Mondes. Programmet var dels at bringe belærende afhandlinger dels æstetiske artikler. Fra 1869-71 var den norske forfatter Bjørnstjerne Bjørnson tilknyttet redaktionen. Også til dette tidsskrift leverede Jørgensen fra 1869 en række afhandlinger, bl.a. om Niels Ebbesen, Tovelille og Saxo, Absalons klerk.

Jørgensen var glad ved samarbejdet med Rudolf Schmidt, hvilket tydeligt fremgår af en række bevarede breve. ${ }^{6}$ I marts 1872 , hvor han var i færd med at forberede en ny artikel til tidsskriftet, offentliggjorde Bjørnson et bidrag, der faldt ham meget for brystet. Artiklen hed Nogle ord til ungdommen. I artiklen frarådede Bjørnson ungdommen at nære pietet overfor dens nærmeste åndelige fædre. Navnlig rettede han et hvast angreb på Carl Ploug og hans skandinaviske ideer, ligesom han kritiserede den fløj af grundtvigianerne, der havde vist sig uvillige til at alliere sig med J. A. Hansens politiske parti. Han angreb desuden de "hele standpunkter ", der ville alt eller intet, og han påkaldte "folkeånden " som den rette kilde til fornyelsen. I et brev til Schmidt 10. april 1872 udtalte Jørgensen, at han ganske vist havde berøringspunkter med Bjørnson og hans ideer, men artiklen vidnede om et så kolossalt fejlsyn hos forfatteren på hans egen person og gerning, såvel som på hele samtiden, og i sine enkeltheder fandt han den "så opfyldt af råheder og tåbeligheder “, at han ikke kunne tænke sig fortsat at være medarbejder ved tidsskriftet. ${ }^{7}$ Et godt begyndt samarbejde endte således med et brud.

Foreløbig koncentrerede Jørgensen sig om at få sine artikler optaget i Årbøgerne og i de Kirkehistoriske Samlinger. Man kan undre sig over, at han ikke forsøgte sig hos redaktøren af Historisk Tidsskrift, professor Edvard Holm. På opfordring havde han ganske vist i 1870 offentliggjort en længere anmeldelse af nogle tyske arbejder om ærkebispedømmet Hamborg-Bremen, men det var først i 1877, at han debuterede i Historisk Tidsskrift med et 


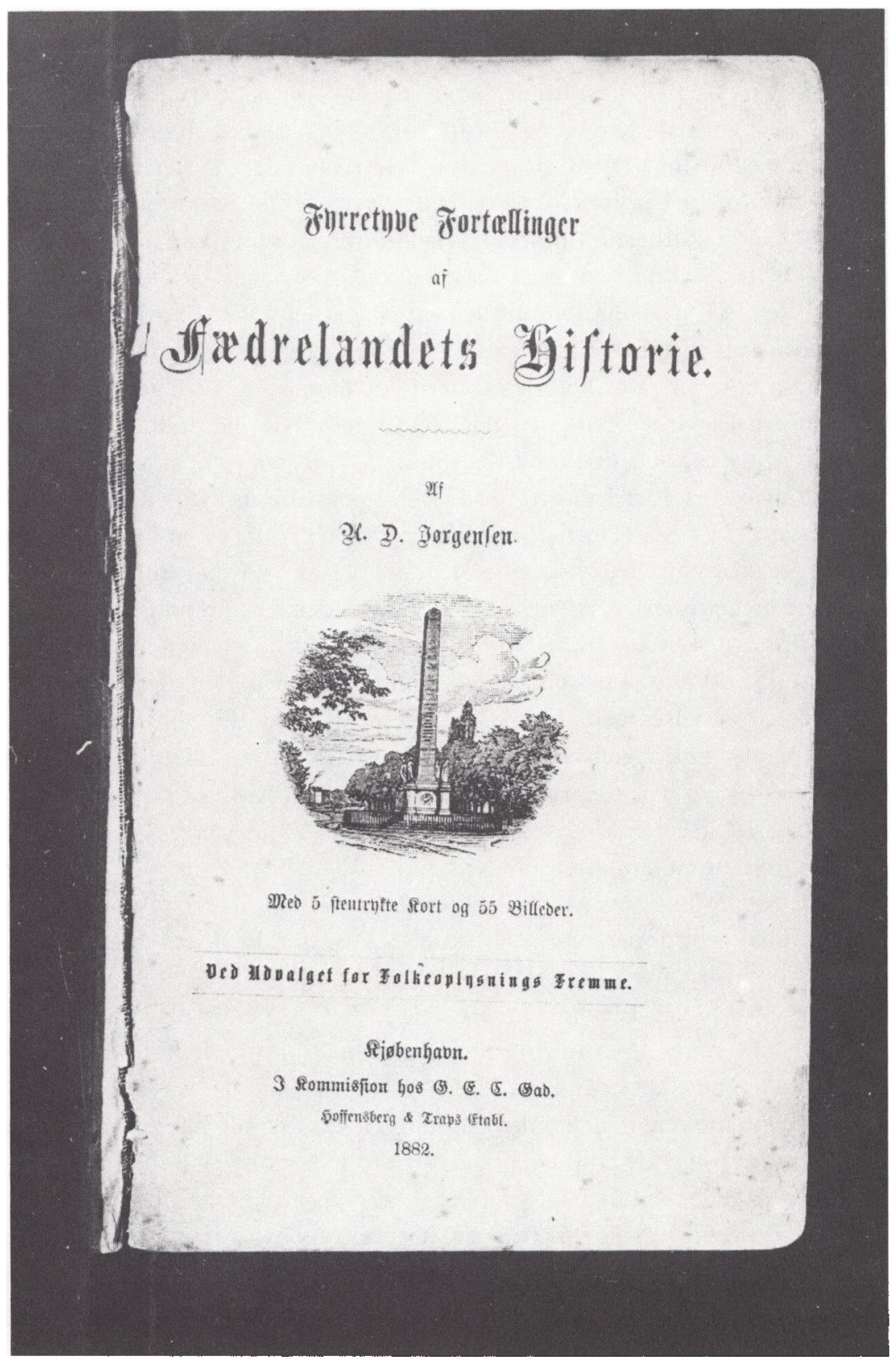

Titelblad til I. udgave af Fyrretyve Fortallinger af Fadrelandets Historie. 1882. 
selvstændigt arbejde, nemlig en artikel om Danebrogs oprindelse, som han forsigtigt gav undertitlen "en historisk hypotese“.

Omkring nytår 1873 besluttede Jørgensen at samle sine studier omkring et større kirkehistorisk emne, og i første omgang tænkte han på en mere omfattende skildring af biskop Absalon. ${ }^{8}$ Han fandt det imidlertid vanskeligt at finde en naturlig begyndelse på dette emne, og lidt efter lidt modnedes den tanke at samle studierne omkring kristendommens indtrængen i Norden. Som afslutning kunne han måske senere fortsætte med Absalon.

H. F. Rørdam godkendte dette forslag, og i et brev af 31. oktober 1873 fremsendte Jørgensen en fuldstændig plan og meddelte samtidig, at væsentlige dele af manuskriptet allerede var færdige. ${ }^{9}$ I årene $1874-76$ udkom 1 . bind af Den nordiske kirkes grundlæggelse og første udvikling, inddelt $i$ to afsnit og omfattende ca. 600 sider. I 1878 fulgte 2. bind (ca. 300 sider), i hvilken fremstillingen blev ført frem til det øjeblik, da Norden blev en selvstændig kirkeprovins i 1135. Hertil sluttede sig optryk af et antal historiske dokumenter og mindre småstykker, der belyste specialproblemer. Ialt omfattede kirkehistorien således ca. 1.000 tryksider. Om årene 1873-76, hvor manuskriptet i det væsentlige blev til, udtalte forfatteren senere, at han så godt som ikke »kunne tænke på noget andet, end hvad der stod eller kunne bringes $\mathrm{i}$ forbindelse med det“. Da bogen omkring 1877-78 omsider var færdigskrevet, var Jørgensen foreløbig blevet træt af at beskæftige sig med middelalderlige emner, og planen om en skildring af Absalon og hans samtid blev aldrig realiseret. Medvirkende hertil kan have været, at den unge historiker og jurist Johannes Steenstrup i 1873 havde udgivet en meget polemisk bog: Studier over kong Valdemars jordebog, hvori han bl.a. meget håndfast havde opponeret mod anskuelser om middelalderlige samfundsforhold, som Jørgensen tidligere havde forfægtet. ${ }^{10}$

Kirkehistorien var tilegnet Jørgensens fader, farver M. A. Jürgensen i Gråsten $\mathrm{i}$ taknemmelig erindring om hans dansk-nationale holdning under det slesvig-holstenske skisma $1848-50$ og hans positive støtte til sønnens studier i København i mellemkrigstiden. På titelbladet havde forfatteren desuden bragt følgende citat fra bogen: "Et folk kan blive gammelt, men det ældes ikke, sålænge det hævder sin plads i verdens udvikling, og det kan ikke dø, sålængde det bliver sig selv tro «. ${ }^{11}$ Citatet er typisk for A. D. Jørgensen og for fremstillingen $i$ kirkehistorien. Den indledtes med en bred skildring af den katolske kirkes udvikling fra pave Gregor den Stores tid omkring år 600 og den senere påbegyndte frankiske mission, der endte med grundlæggelsen af bispedømmerne i Hamborg og Bremen. Herefter fulgte en udførlig redegørelse for missionen i de nordiske lande og oprettelsen af de nordiske bispedømmer samt baggrunden for den endelige stadfæstelse af den særlige 
nordiske kirkeprovins i 1135 . Den store kirkehistorie må betragtes som et af datidens vægtigste bidrag til Nordens ældste historie.

Når det trak ud med færdiggørelsen af kirkehistorien, hang det sammen med, at nye interessante opgaver havde meldt sig. Et tilfældigt fund af et kongebrev til anatomen og geologen Nils Steensen førte til, at Jørgensen i en vis periode koncentrerede al sin energi om udforskningen af denne mands omskiftelige tilværelse, en af 1600-tallets mest originale forskere, hvis videnskabelige indsatser først og fremmest blev til i udlandet. Bogen om Steno blev dog først udgivet i $1884 .{ }^{12}$ I 1879 stødte Jørgensen på en anden interessant videnskabsmand, nemlig oldforskeren Georg Zoega. Zoega var født i Daler ved Højer og langt ude i slægt med Jørgensen. Også denne personlighed, der havde visse ligheder med Steensen - begge gik i moden alder over til katolicismen og opholdt sig i lange perioder i Italien - fangslede ham meget. Bogen om Zoega udkom i 1881. ${ }^{13}$ Den var på 230 sider og udsendtes af Samfundet til den danske litteraturs fremme, som også i 1884 udgav Steno-bogen.

I 1877 henvendte historikeren H. H. Lefolii, siden 1866 rektor ved Viborg katedralskole, sig til Jørgensen om forslag til udgivelse i dansk oversættelse af egnede historiske kildeskrifter. ${ }^{14}$ Rektor Lefolii havde sammen med nogle venner i 1875 stiftet et særligt selskab med dette formål. Man havde egentlig tænkt sig en oversættelse af oldtidens og middelalderens historiske kildemateriale, men Jørgensen anbefalede danske tekster. "Der slår én en ganske ejendommelig luft af det faktiske imøde ud af disse aktstykker; læseren af historiske fremstillinger er så vant til at få alting på anden hånd, at selve dokumenterne overrasker og får en egen tillokkelse “. ${ }^{15}$ Som et konkret forslag anbefalede Jørgensen en samling af kilder til Valdemar Sejrs historie. Lefolii tog forslagsstilleren på ordet og bestilte en samling dokumenter fra Valdemar Sejrs tid. Sin vane tro gik Jørgensen straks igang med udførelsen, og i 1879 udsendtes Valdemar Sejr. Udvalgt samling af samtidige kildeskrifter og oldbreve i dansk oversættelse, omfattende 223 sider.

Selv om Jørgensen i 1870 'erne i første række koncentrerede sig om sit historiske forfatterskab, som målt i tryksider var ganske omfattende, havde han ingenlunde opgivet interessen for at beskæftige sig med friere og mere vidtgående studier $\mathrm{i}$ europæisk åndsliv. En periode var han således stærkt optaget af den italienske digter Dante Aligheris berømte digt Den guddommelige Komedie, og senere kastede han sig over den tyske digter og filosof C. M. Wielands (1733-1813) omfattende forfatterskab. Studier af denne karakter var som åndelige frikvarterer i den daglige beskæftigelse med historiske problemer.

Endnu inden kirkehistorien var færdig, meldte en ny stor opgave sig for 
ham. Under indtryk af den nationale udvikling i Nordslesvig stod det ham klart, at han burde samle sig om en skildring af Sønderjyllands historie, og at han af alle var nærmest til at løse denne opgave. "Det gik nu pludselig op for mig, at jeg her måtte tage fat" skriver han i redegørelsen. ${ }^{16}$

En forårsdag i 1876 - han skriver selv 19. maj - lagde han planer om at forfatte 5-6 skrifter Af Sønderjyllands historie, i hvilke han ville imødegå de tyske påstande om hertugdømmets særstilling samt genopf riske mindet om dets tusindårige samliv med kongeriget. Han talte med sin gode ven tømrermester Kayser om sin plan, og denne lovede økonomisk støtte. Tømrermester H. H. Kayser - en kendt københavnsk håndværksmester og politiker - havde inden for den i 1865 stiftede kongerigske Forening Danebrog udført et stille, men fortjenstfuldt arbejde til støtte for nationalitetskampen i Nordslesvig. Man diskuterede nu, hvilke emner der skulle tages op, og man enedes i første omgang om en fremstilling af sønderjyderne i den danske hær. Formålet skulle være at vise, at den tyske påstand om, at sønderjydernes våbenhæder først begyndte med deres deltagelse i den tyskfranske krig 1870-71 var forkert. Bogen blev skrevet i løbet af 5 uger og udkom i 1876 hos Gyldendal. Titlen på den planlagte skriftserie blev Af Sønderjyllands historie, og titelbladet var prydet med en tegning af det ældst kendte sønderjyske våben med de to løver, nemlig hertugseglet fra 1260 . Bogen, der var på 137 tryksider, byggede hovedsagelig på militærhistorikeren O. Vaupells kendte store værk om den dansk-norske hærs historie, der var udkommet $\mathrm{i}$ årene 1872-76. Bogen var inddelt $\mathrm{i} 7 \mathrm{afsnit}$ og begyndte med en skildring af middelalderens hære. I kapitlet om de store krige i begyndelsen af 1700-tallet, hvor Frederik 4. lod udruste forskellige danske korps, som deltog i forskellige slag på europæiske slagmarker under ledelse af datidens store feltherrer, hedder det: "Alle de tropper, som var hvervede i eller knyttede til Sønderjylland, deltog i disse mindeværdige ekspeditioner, der kastede glans over det danske navn blandt alle Europas folk og stillede landsoldatens hæder ved siden af orlogsmandens. Tidens største feltherrer ... holdt dem blandt de bedste i deres arméer og overøste dem med ros og udmærkelse «. ${ }^{17}$ Den lille bog afsluttedes med en skildring af kampen om Sønderjylland 1848-50 og 1864, hvortil forfatteren havde benyttet visse personlige erindringer. I dette afsnit var hovedvægten lagt på at følge de særlige sønderjyske afdelinger. I nogle slutningsbemærkninger førte forfatteren fremstillingen op til nutiden: "Freden $\mathrm{i}$ Wien har udelukket sønderjyderne fra den danske hær, forsåvidt som en fredsslutning kan gøre det. Thi endnu strømmer de til fanerne, endnu står de »under Danebrog “; som i Svend Grathes tid er de i tusinder gået mod nord og har opgivet deres hjemland for at bevare troskaben mod fædrelandet «. ${ }^{18}$ Hermed tænkte forfatteren på de mange unge 
mænd, der var udvandret fra Nordslesvig for at undgå at blive preussiske soldater.

Jørgensen var senere ikke helt tilfreds med bogen, som han karakteriserede nærmest som en overilelse. "Fremstillingen var i det hele for tør og stoffet for tungt behandlet $«$. Han mente dog, at den havde gjort nogen nytte ved »midt i en død tid at bryde den tavshed, som havde lagt sig over vor sag, og den gav anledning til den første livlige forhandling i de nordslesvigske blade om genoprettelsen af danske bogsamlinger ${ }^{1.9}{ }^{19}$ Netop oprettelsen af bogsamlinger var ved at blive et aktuelt spørgsmål såvel i Nordslesvig som $\mathrm{i}$ kongeriget, og af et brev til landøkonomen J. C. la Cour fra 13. februar 1880 ser man, at Jørgensen personligt var interesseret i dette spørgsmål. ${ }^{20}$ Senere på året oprettedes som omtalt foran den nordslesvigske sprogforening.

Planen om en serie af småskrifter om sønderjyske emner blev ikke videreført, formodentlig fordi Jørgensen nu besluttede at skrive en stor Sønderjyllands historie, bygget på originale kildestudier. Samtidig havde han også planer om at få tilvejebragt en kortere og mere populært anlagt fremstilling, som imidlertid først skulle udkomme, når det store værk var afsluttet. Fra 1880 lagde han alle andre opgaver til side for at samle sig om sit egentlige kald at skrive Sønderjyllands historie. Han tog fat på en gennemgang af det middelalderlige kildemateriale og gennem et brev til hans senere medarbejder $\mathrm{i}$ arkivet $\mathrm{V}$. A. Secher, dateret 8 . februar 1881 , får vi et kig ind $\mathrm{i}$ hans historiske værksted. ${ }^{21}$ Han havde på det tidspunkt nærmest afsluttet skildringen af Sønderjyllands historie indtil 1544, som var tænkt som et første bind. Herefter skulle følge et bind om "Delingstiden " omfattende perioden 1544-1721. Den efterfølgende periode indtil 1864 skulle herefter fylde to bind ". "Men hvad det hele skal blive til uden en ganske anderledes adgang til gehejmearkivet, aner jeg ikke“. Der har åbenbart på det tidspunkt været visse vanskeligheder med gehejmearkivets aldrende chef C. F. Wegener, som i øvrigt med udgangen af 1882 tog sin afsked og fra nytår 1883 afløstes af Jørgensen.

Midt under disse studier modtog Jørgensen en opfordring til at give en fremstilling af udviklingen i Nordslesvig efter 1864, altså et ganske aktuelt emne. Hans opdragsgiver var den kendte journalist og national-liberale politiker C. St. A. Bille. Bille, der i øvrigt mest er kendt som grundlægger og mangeårig redaktør af det national-liberale hovedorgan Dagbladet, var $\mathrm{i}$ sommeren 1878 rejst til London for på det kgl. landhusholdningsselskabs vegne at forsege at hindre et engelsk forslag om at standse den frie danske kreatureksport til det engelske marked. Fra gammel tid havde Bille nære kontakter med førende engelske pressefolk indenfor så fremtrædende blade som The Times og Daily News, og han havde desuden forbindelser til visse 
politikere. Han har åbenbart ønsket under besøget i London at virke for den danske befolknings truede stilling i Nordslesvig. Han anmodede nu A. D. Jørgensen om at udarbejde en betænkning, som han lod oversætte til engelsk. Om Bille har tænkt sig, at det nordslesvigske spørgsmål kunne blive rejst $\mathrm{i}$ forbindelse med den internationale konference, som Bismarck havde indkaldt til Berlin for at drøfte Balkanspørgsmålet efter den russisk-tyrkiske krig, er muligt. Konferencen åbnedes i Berlin 13. juni 1878 og afsluttedes med underskrivelsen af fredstraktaten af 13. juli 1878. Kongressen beskæftigede sig imidlertid udelukkende med, hvad man kaldte "Europas syge mand " (Tyrkiet). ${ }^{22}$

Nogle måneder efter kongressens afslutning indgik Preussen sin aftale med $\varnothing$ strig om § 5's ophævelse, og Jørgensen besluttede herefter at omarbejde sin betænkning og udsende den anonymt under betegnelsen En Nordslesviger. Den offentliggjordes i højskoleforstander Rasmus Hansens tidsskrift Dansk Folkeblad og udkom som særtryk i 1880 under titlen Den nationale stilling i Nordslesvig i anledning af traktaten af 11 . oktober 1878. (40 sider). Nogle uddrag af pjecen indgår passende som baggrund for det følgende.

Indledningsvis fastslås det, at traktaten af 11 . oktober 1878 totalt har ændret forholdet mellem Danmark og Tyskland. Det statsretlige begreb Nordslesvig eksisterer ikke mere, og håbet om at få afsluttet de evindelige grænsestridigheder er tilintetgjort. De venligere følelser, der var ved at udvikle sig mellem de to folk, har foreløbig mistet sin rod. "Hvis dette er denne nabos sidste ord i sagen, vil det være umuligt at tænke sig en fremtid i god forståelse med Tyskland, vi må berede os på at gå prøvelser imøde, som det vil være uforsvarligt at lukke øjet for «. ${ }^{23}$ Efter en gennemgang af den preussiske administration, hvis formål har været "at optugte en ny slægt $\mathrm{i}$ Nordslesvig, en slægt af preussere « spørger forfatteren: har dette land en fremtid? Svaret lyder: „Endnu er stunden vor. Nordslesvigs håb hviler sikkert på den nuværende slægt; den er stærk ved sin fortid, den er på det rene med, hvad overgangen under tysk herredømme har bragt og fremdeles vil bringe, den føler det som en national ulykke at skulle regeres af tyske embedsmænd, at dømmes af tyske dommere, at sende sine børn i en tysk skole og at lade sin ungdom sværge til den tyske fane. Den danske nationalitet er for denne slægt en hellig arv, som den vil gøre alt for at lade gå uforvansket til sine børn «. ${ }^{24}$ De vil ikke falde fra, hedder det videre, og de har walle betingelser for at fortsætte et nationalt liv så rigt og så ædelt som noget andet folk “. Forfatteren har en fast tro på denne befolkningsgruppes fremtid. "Der vil komme en dag, da verdensbegivenhederne vil kræve Tyskland til regnskab for sine overgreb mod et værgeløst nabofolk. Denne dag kan måske være fjern endnu, men den kan også være nærmere, end nogen aner; den vil ikke for os være en hævnens 
og gengældelsens, men den bør kunne blive en national genfødelsens dag. Denne tanke pålægger alle danske en alvorlig og uafviselig pligt “. ${ }^{25}$ I Nordslesvig bør man ikke tabe tålmodigheden, men overveje, hvad der kan gøres for at bevare børnenes fremtid. De »bør fremfor alt værge modersmålets ret. Og de bør overveje, om de ikke kunne bringe endnu større ofre end hidtil, vise endnu større selvfornægtelse for at bevare deres hjem mod det fremmede «. ${ }^{26}$ Forfatteren har utvivlsomt det alvorlige spørgsmål i tankerne, som var ved at blive brændende i mange nordslesvigske hjem, om det ikke var rigtigt, at den opvoksende ungdom underkastede sig preussisk militærtjeneste for herigennem at sikre sig ret til at forblive og virke i hjemstavnen. Det udtales ikke udtrykkeligt, men det tilføjes, at det er mingen ydmygelse at bøje sig under tilskikkelsen, hvor modstand er umulig; bedre er det at bøjes end at brydes «. Også $i$ kongeriget bør man overveje, om man ikke i højere grad end tidligere må kunne mødes i fælles arbejde for det fælles mål. Med hensyn hertil så Jørgensen det som $\sin$ første og vigtigste opgave at få skrevet den planlagte Sønderjyllands historie. Pjecen sluttede med denne appel: "Vor mægtige nabo har stillet os på et vendepunkt i vor nationale velfærdssag: lad så være, at han har tænkt derved at tilføjes os et tungt slag, at kvæle vort håb og bringe vor tålmodighed til at briste; det står til os selv med Guds hjælp at vende alt til det gode ${ }^{27}{ }^{27}$

Håbet om en genforening havde Jørgensen stadig $\mathrm{i}$ behold, og han bevarede det usvækket også i fremtiden. Hverken i den her citerede pjece eller senere udtalte han sig mere konkret om, hvor den fremtidige dansk-tyske grænse skulle trækkes. Han taler fortrinsvis om Nordslesvig og kalder sig selv en Nordslesviger. Men hvad forstod han med Nordslesvig eller formuleret på en anden måde: Håbede han endnu på dette tidspunkt, at Flensborg, hvor han havde tilbragt rige ungdomsår, kunne følge med tilbage til moderlandet, eller havde han afskrevet denne mulighed? Spørgsmålet må stå åbent, da der ikke foreligger klare tilkendegivelser herom. Det kan imidlertid have interesse at gøre opmærksom på, at han omtrent samtidig med pjecens fremkomst havde en offentlig debat med Frederik Barfod, der i Dansk Folkeblad i december 1879 havde skrevet en artikel om Danmarks grænse, og hvori han havde sammenfattet sin opfattelse af grænsespørgsmålet i følgende linier: »hvor Uffe slog og vandt, er Danmarks grænse “, altså Ejderstrømmen. Jørgensen svarede omgående og anonymt i samme tidsskrift, og i et efterfølgende brev til Barfod, dateret 11. januar 1880, motiverede han nærmere sin afvisning af et Danmark til Ejderen som et fremtidsmål. "Vi lever $i$ en virkelig verden, og vi må tale virkelighedens sprog til den slægt, der skal bære fremtiden «, og den er aldeles ikke at få i tale, når vi nævner Ejderen. "Jeg skulle måske ikke have kaldt det "bitterhed «, hvad vi føler ved tanken 
26. Snboig Solberg.

295

frem for at benoende fig til bet ferbe Evropa $i$ et fremmes Daat. San oplebebe ba ogiaa, at ber oprettebes et banft .Bibenffabernes Selflab" (1742), hois Meblemmer forplig. tebes til at fremlagge beres \&rbejoer $\mathrm{i}$ Mloder 8 maalet.

Beb benne ftore Birfiombed vandt 5olberg med

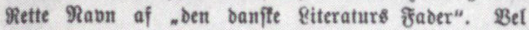
havbe vi fer ham en Ratfe fremragenbe irorfattere $i$ MRoberemaalet, iffe blot i Reformationeaarbunbrebet, men ogfaa $i$ ben efterfolgenbe $T i b$, ber $i$ bet hele var ugunftig for ben folfelige Dplyaning. 3 geriftian 4.8

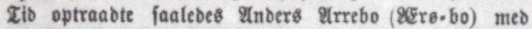
en meget laft Digtning om "De 6 Dages (Sjerning", og 1 striftian 5.8 Iib ubgav I bomas $\Omega$ in go fine Salmer, (not aanbelige Sjungetor"), Der inbtil ben Dag i Dag har hert til ben banfle Sirfes ppperite Statte. Men intet af bette tom bog til at Danne Ubgangepunttet for en fammenbangenbe siteratur, ber funde figes at vare at levende ustrylt for banff Folfeejenbommelighed og forene hele ben banfle sajeberben i en falles aanbelig Utovifling. Dette bar berimob i fulbefte Mlaal Ill= falbet med Solbergs talrige Strifter.

Dolberg bobe 1754 fom en Mano paa 70 शar; han banbt beb fine Strifter iffe blot 2 Gre, men ogfaa Rigbom, ag ba ban bobe, bar han Baron meb et fitort Baroni./ Dette lgev-hen, ugift og aben nax Sloxgt fom han bar, til Sienoprettelfen af bet i sriftian ben fierbes $\mathfrak{x}$ id grunblagte, men fenere nedlagte $2 f_{a} b \mathrm{~cm} i$ i $\sigma_{0}$ oro, fom han enftebe ombannet til en Deiffole for unge Pano af alle Stander. Denne Ianfe foun bog iffe til ub. ferelfe, og 3ndtxgterne a) bans ftore 3orbegods anven= bes nu, foruben til ben larbe Stole i Sorb, ogfa til Theatret, til unberftettelje af Sunftnere og 2 ibeniftabs: atonb, Ëolfehejftolex og Realffoler, til ubdannelie af Eerexe og Reererinber og til talrige anbre former for bet

Egenhandige rettelser til 2. udgave af fortallingen om Ludvig Holberg, A. D. Jorgensen lod som regel et eksemplar of sine bøger indbinde med indskudte hvide blade, säledes at han kunne foretage onskede rettelser.

om Ejderen, vel at mærke som fremtidsmål ... men det er dog vistnok det retteste navn. De har aldrig følt den brod i Deres hjerte, som sydslesvigernes forræderi efterlod i hver dansk sønderjyde; De har ik ke oplevet de øjeblikke, da disse mænd anråbte udlandets indblanding, da de drog til Berlin, mens vore brødre blødte på Dybbøl, da de satte himmel og jord i bevægelse for at hindre en endelig retfardig afgørelse, som kunne have reddet os fra landflygtighed og vort hjem fra at blive fjendernes ejendom. Ja, De har aldrig ædt landflygtighedens bitre brød, kære hr. Barfod; De er aldrig kommet hjem 
og har fundet Deres barndomsminder ødte, og alt hvad der var Dem kært skændet og tabt. De har aldrig tænkt Dem, at man kan forbande sin barndoms træer, fordi de smykkede sig troløst for et fremmed folk, eller føle en brand i sit hjerte, fordi søen er lige frisk og lige skøn omkring en tysk orlogsmand, som den var før. Og dette skyldes vore tidligere landsmænd, det er fremkaldt, udviklet og fuldendt af dem, - skulle vi kunne ønske at drage dem med os over til et fremtids fædreland? Bliv ikke forundret over, at vi føler det bittert, når danske folk vil det så «. ${ }^{28}$ Ingen kan være i tvivl om, at Jørgensen brændende ønskede en fremtidig deling af det omstridte land, således at kun den danskfølende del kom tilbage. Men hvor grænsen skulle trækkes, fremgår hverken af indlægget eller brevet til Barfod.

Perioden 1868-81 havde været en frugtbar periode i forfatterskabet. En rig høst var bragt $i$ lade. En række historiske afhandlinger og selvstændige værker havde set dagens lys. Tilskyndelsen til udarbejdelsen af visse litteræ re opgaver var kommet udefra, og de var blevet udført prompte. De fleste opgaver var dog udsprunget af forfatterens egen interesse og fremstillet med varme og personligt engagement. I begyndelsen af året 1881 havde forfatteren et nyt stort værk på beddingen, nemlig den store Sønderjyllandshistorie, hvis fuldendelse han betragtede som et personligt kald. Da modtog han imidlertid uventet en ny opfordring udefra, som han ikke mente at kunne afvise. Det medførte, at arbejdet på det store vark gik istå, og som vi ved, blev det aldrig genoptaget.

\section{Tilblivelsen af de 40 fortællinger af fædrelandets historie}

Om den nye opgave, som blev ham overdraget, skriver A. D. Jørgensen. De mange klager fra Nordslesvig gående ud på, at forældre stod værgeløse overfor deres børns lærere, medførte i foråret 1881 , at brygger Jacobsen satte "sig i bevægelse for at få en kortfattet Danmarkshistorie skrevet til udbredelse derovre, og ad forskellige veje henvistes han til mig for at få denne plan virkeliggjort. Jeg påtog mig det selvfølgelig med glæde, da det jo faldt sammen med mine egne planer, men jeg skjulte ikke for mig selv og andre, at det kunne blive skæbnesvangert for den større Sønderjyllands historie. Min plan blev da at fortælle fædrelandets historie $i$ en række indbyrdes uafhængige stykker, der til den ene side skulle gøre fuldt rede for hertugdømmets politiske og nationale udvikling, til den anden fremdrage de bedste og rigeste minder af rigets samlede historie. Dette gik Jacobsen villig ind på, og jeg optoges nu aldeles af dette arbejde. Det fuldførtes $\mathrm{i}$ løbet af et fjerdingår, idet nogle af fortællingerne blev nedskrevne $\mathrm{i}$ få timer, medens andre krævede omfattende undersøgelser og gentagne tilløb «. ${ }^{29}$ Denne ret 
kortfattede notits kan og bør imidlertid nærmere eftergås og videre udbygges. $^{30}$

I ovenstående citat nævnes kun en enkelt person, men ganske vist en overmåde betydningsfuld skikkelse. J. C. Jacobsen var grundlægger af bryggeriet Carlsberg og havde haft en eksempelløs fremgang som forretningsmand. En ikke ringe del af sine rige indtægter havde han $i$ de forløbne år skænket til videnskabelige og nationale formål. Han havde bl.a. oprettet Carlsbergfonden og medvirket aktivt til genopbygningen af Frederiksborg slot og indretningen af det kommende nationalhistoriske museum. Nu stillede han i første omgang $9.000 \mathrm{kr}$. til rådighed til fremskaffelse af en Danmarkshistorie, som han ønskede trykt i 10.000 eksemplarer og gratis uddelt i Nordslesvig. Senere øgede han sit bidrag til $15.000 \mathrm{kr}$. Hans tilbud var således en væsentlig forudsætning for, at arbejdet kom i gang.

Men hvorledes fandt han frem til A. D. Jørgensen? Meget tyder på, at det var den allerede tidligere næunte tømrermester Kayser, der formidlede forbindelsen, og det er måske også ham, der havde nære kontakter bl.a. med den nordslesvigske sprogforening, der har fået Jacobsen ind på tanken om at få skrevet den ønskede Danmarkshistorie. Endnu en tredje person må nævnes, nemlig den historiske forfatter og tidsskriftsudgiver dr. Mathias Steenstrup, der $\mathrm{i}$ årene $1876-88$ desuden virkede som statens tilsynsførende ved de mange nyoprettede folkehøjskoler. Han havde i 1866 stiftet Udvalget for folkeoplysnings fremme, som igennem årene ved udsendelse af oplysende og populære skrifter i høj grad havde bidraget til at fremme læselysten i de bredere kredse. Han var desuden en nær ven af brygger Jacobsen og af tømrermester Kayser.

Det idag tidligst bevarede skriftlige vidnesbyrd om arbejdets igangsættelse er Jørgensens egenhændige udkast til en plan for værket. Det er et dobbeltark på fint papir og underskrevet og dateret maj 1881. Som overskrift har dokumentet følgende: "Udkast til Fyrretyve Fortællinger af Fædrelandets Historie." Herefter følger forslag til de enkelte fortællinger og en kort, nærmere forklaring, hvis overskriften til den enkelte fortælling ikke var tydelig nok. Det kan da fastslås, at forfatteren allerede på dette tidlige tidspunkt havde lagt sig fast på bogens titel og antallet af fortællinger. Hvorfor han standsede ved tallet $40 \mathrm{og}$ ikke 35 eller et højere tal, forklares måske af det forhold, at han havde forelsket sig i bogstavrimet i titlen: Fyrretyve Fortællinger af Fædrelandets Historie.

Når man erindrer sig, at forfatteren i foråret 1881 i sin store Sønderjyllands historie var nået frem til ca. år 1544, er der måske intet mærkeligt $i$, at lidt over halvdelen af de foreslåede kapitler behandlede dette tidsrum. Det er vel heller ikke så mærkeligt, at der i det første udkast var flere selvstændige kapitler om 
den danske kirkes grundlæggelse. Med kapitel 23 var han nået frem til Christian 4., og i de følgende 10 kapitler behandledes perioden 1588 til ca. 1800. Til den nyeste tid var således kun afsat 9 kapitler. Det er også karakteristisk for det første udkast, at mange kapitler som overskrift havde fået en central personligheds navn, såsom Ansgar, Tyre Danebod, Knud Lavard, grev Gert, Valdemar Atterdag og dronning Margrethe m.fl. I mindre grad var dette tilfældet med de sidste 100 års historie. Her havde selve begivenhedsforløbet præget overskrifterne.

Sandsynligvis er udkastet blevet drøftet indenfor udvalgets bestyrelse, der foruden Steenstrup som formand bestod af den københavnske skolebestyrer Martin Hammerich, den tidligere præst i Halk ved Haderslev professor H. V. Rasmussen, der efter sin fordrivelse fra Slesvig i 1864 havde virket ved forskellige københavnske skoler og været eksaminator ved skolelærer- og skolelærerindernes eksamenskommission, den ivrige grundtvigianer og særprægede venstrepolitiker N. J. Termansen og den kendte docent og forsøgsleder ved landbohøjskolen N. J. Fjord. ${ }^{31}$ Udvalget holdt møde $i$ slutningen af juni 1881, og Steenstrup kunne bagefter fortælle brygger Jacobsen, at udvalget var positivt indstillet overfor det planlagte skrift, og at man ville fastholde, "at udvalgets frihed overfor teksten måtte bevares fuldstændig som ved vores andre skrifter. I denne henseende kunne jeg oplyse, at dette stemmede så vel med Deres som med forfatterens tankegang «. Udvalgets behandling af udkastet medførte en bedre balance i bogen. Visse kapitler fra den ældste periode blev skåret væk eller sammentrængt, således at behandlingen af den nyere og nyeste historie kunne blive udvidet. Antallet af fortællinger - 40 - blev fastholdt også i den reviderede plan, og titlen blev ikke ændret.

Steenstrup havde i mellemtiden også undersøgt omkostningerne ved udgivelsen, og i et brev til Jacobsen af 21 . maj 1881 fremlagde han et overslag over udgifterne til fremstilling af de 10.000 eksemplarer, der skulle uddeles i Nordslesvig. I sit svarbrev af 23. maj 1881 udtrykte Jacobsen sin glæde over, at udgifterne tegnede mindre, end han havde tænkt sig. Han havde regnet med $9.000 \mathrm{kr}$., inclusive forfatterhonoraret. Da der nu viste sig at blive penge til overs, foreslog han, at man brugte disse til at bringe illustrationer i bogen. Han ville endvidere gerne deltage $i$ udgiften til sætning af hele oplaget, inclusive de 5.000 eksemplarer, som udvalget havde reserveret for sig selv til salg i kongeriget, "da det dog også ligger mig på hjertet, at bogen kan blive udbredt så meget som muligt $\mathrm{i}$ kongeriget . Forslaget om at illustrere bogen forelagdes og godkendtes på det ovenfor næunte udvalgsmøde. Da det under det videre arbejde med bogen viste sig, at den bl.a. på grund af de mange illustrationer og oplysende kort blev væsentlig dyrere end først beregnet, 


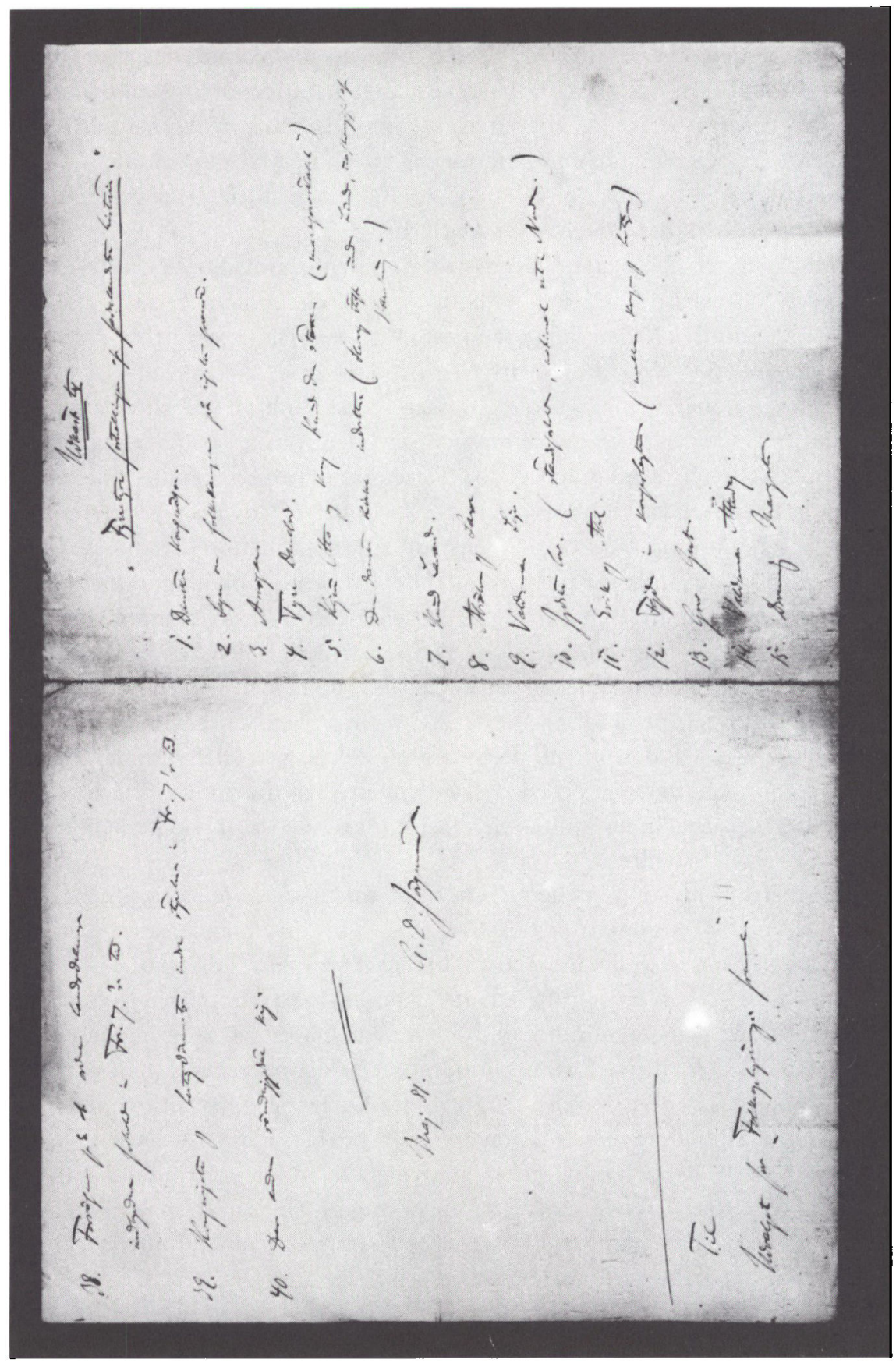




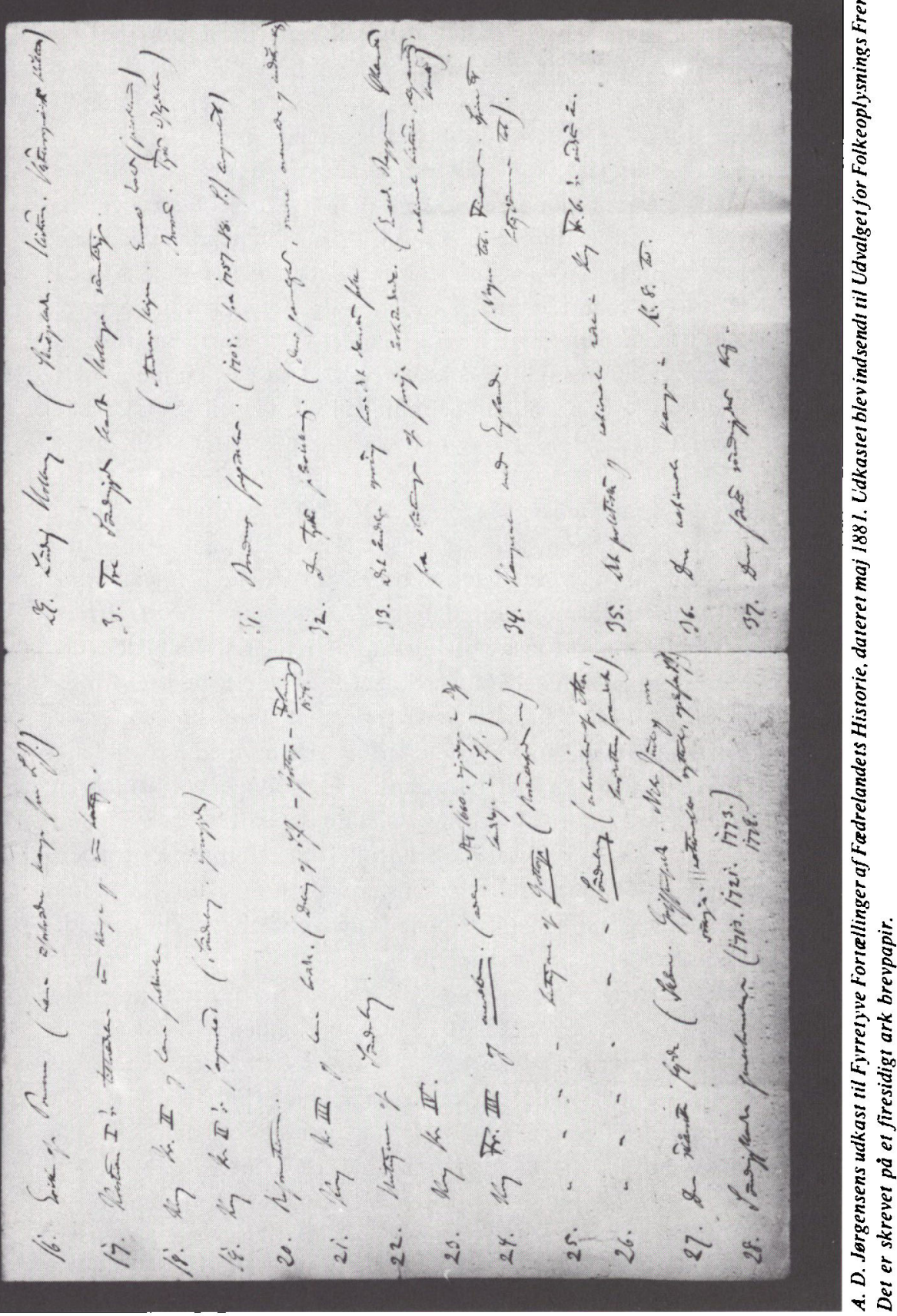


forhøjede Jacobsen sit bidrag til $15.000 \mathrm{kr}$., inclusive honoraret til forfatteren.

Man må herefter kunne gå ud fra, at Steenstrup omkring 1. juli 1881 har kunnet meddele forfatteren, at han kunne gå i gang med arbejdet. Det er formodentlig påbegyndt i lobet af sommeren 1881 og efter forfatterens ovenfor citerede udtalelse fuldendt $\mathrm{i}$ løbet af et fjerdingår.

Betegnelsen "et fjerdingår « skal nu ikke tages ganske efter pålydende. Som det nedenfor vil blive dokumenteret, kan man ret nøje fastlægge den tidsramme, indenfor hvilken bogen blev skrevet. Selv om denne må opgøres til 7 måneder, er der ingen tvivl om, at forfatteren var en hurtigløber. Alene et blik på hans bevarede manuskripter viser, at stålpennen er fløjet henover papiret, når forfatteren følte sig grebet af emnet. Det korte tidsrum for udarbejdelsen hænger naturligvis også sammen med, at han kunne udnytte foreliggende manuskripter, navnlig til belysning af tiden indtil 1544. Det skal derfor nok være rigtigt, at nogle af fortællingerne er blevet skrevet i løbet af et par timer.

Allerede i slutningen af august 1881 forelå de første fortællinger. I et brev af 27. august 1881 tilstillede Steenstrup sine bestyrelsesmedlemmer de første 6 fortællinger til gennemsyn. Næste gang vi hører om arbejdets forløb er i et brev fra forfatteren til Steenstrup, dateret 13. november 1881. Brevet indeholder først $\mathrm{og}$ fremmest forslag til illustrationer, men til slut hedder det: "Da nu godt og vel første halvdel af fortællingerne er aldeles færdige for mit vedkommende, og den anden halvdel ligeledes er vidt fremskreden, er der selvfølgelig for min skyld ingen grund til at vente med de endelige dispositioner. Såsnart gennemsynet af de færdige fortællinger er tilendebragt og de deraf muligvis følgende forandringer afsluttede, kan trykningen godt begynde og vil da kunne fortsættes uafbrudt, hvis intet uforudset træder i vejen «. ${ }^{32}$ Endelig kan man nævne Jørgensens brev til Steenstrup af 8. januar 1882 , hvor han meddeler, at han er færdig med de 10 sidste fortællinger, idet de 5 er hos afskriveren, de næste 4 gennemgået af A. F. Krieger og den sidste, 1864, er skrevet i udkast. ${ }^{33}$ Jørgensen havde gennem flere år haft personlig kontakt med juristen og politikeren A. F. Krieger, og denne havde kritisk gennemgået manuskripterne til kapitlerne om den nyeste historie. Det kan herefter fastslås, at manusk riptet i sin første udformning var blevet til over en periode af ca. 7 måneder - på ingen måde en ringe præstation, da det drejede sig om et manuskript, der i trykt form omfattede 467 sider.

Der er bevaret skriftlige udtalelser fra enkelte styrelsesmedlemmer, som her kort skal omtales. I et brev til Steenstrup af 5. oktober 1881 skriver professor Rasmussen, at bogen "gør et særdeles godt indtryk og bebuder en værdifuld forøgelse af "Folkeskrifterne». Det, at fortrinsvis sønderjyske 
personer og steder drages ind $\mathrm{i}$ sammenhængen, er en såre smuk og tidssvarende tanke, den ualmindelig fædrelandskærlige forfatter værdig. Det kunne befrygtes, at dette nu og da ville give planen noget manieret (?), og unægtelig gik jeg $\mathrm{i}$ den henseende lidt ængstelig til læsningen af "Tre sønderjyder blandt Holbergs samtidige“. Men ved nærmere gennemlæsning har jeg ikke fået denne frygt stadfæstet. Jeg kunne have ønsket, at Brorson som den af de tre, der står størst og dybest i folkets bevidsthed, var næunt først, og ligeledes at de tre levnedsløb var bleven lidt mere individualiserede, således t.e. Enevold Ewalds, om hvem A. D. J. har fortalt mig flere mærkelige småtræk.« Også på et senere tidspunkt udtalte professor Rasmussen sig yderst positivt om bogen.

Det samme gjorde Termansen, som i et langt brev til Steenstrup, dateret 4. december 1881 udtalte, at han med ublandet glæde havde læst de modtagne prøver." Det vil blive en fædrelandshistorie for folket, der på en gang vil være let læselig og tillige give en ligeså klar som grundig oversigt over folkets liv og udvikling gennem tiderne. Hver enkelt fortælling er valgt så heldig og udført med så megen historisk kunst, at den danner et middelpunkt, ud fra hvilket hele omkredsen bliver oplyst, og tråden er fastholdt således, at der på intet tidspunkt $i$ historien bliver noget væsentlig hul. Fortællingerne bærer fra først til sidst præg af et alsidigt og grundigt kildestudium og ikke mindre af et selvstændigt blik på begivenhederne, der ikke lader sig vildlede af nedarvede opfattelser, der ikke kan stå prøve for en indgående undersøgelsee af alle de henhørende kilder. Vi kan ønske os til lykke med, at udgivelsen af et folkeskrift som dette bliver udvalget til del “.

Fra Steenstrup findes også en karakteristik af værket, men på et relativt sent tidspunkt, nemlig $i$ et brev til forfatteren, dateret 7. januar 1882. Han finder fortsat indholdet interessant, men mener, at det er strengere nu, end det $\mathrm{i}$ begyndelsen så ud til, det kræver på sine steder ældre og modnere læsere end ungdom på en snes år». Og han tilføjer: "Jeg ved ikke, hvorvidt der hist og her kunne være valgt stof, der gav anledning til fyldigere, farverigere fortællinger «. En anden indvending var anvendelse af mange etymologier enten egne eller andres, og at der fremsattes synspunkter, der formentlig ik ke havde kunnet prøves af videnskaben, selv om de var rigtige. Udglattende tilføjedes: "De forstår mig nok: jeg mener ikke, at De ikke her må fremsætte, om det så var forste gang. en ny anskuelse, men det er også klart, at en forfatter i et skrift som dette må holde meget tilbage, som han i et skrift for dannede eller for belæste historikere uden videre ville benytte«. Dette til velvillig optagelse. Faktisk var de her fremsatte kritiske bemærkninger, også kritikken mod anvendelse af etymologierne, en afdæmpet gengivelse af de yderst kritiske indvendinger, som Steenstrups nevø, den kommende historie- 
professor Johs. Steenstrup på opfordring havde meddelt onklen i et langt brev af 5. januar 1882. Navnlig "Jørgensens teorier" var han meget kritisk overfor. Jørgensen svarede omgående i et langt brev af 8 . februar 1882 , hvori han vedkendte sig, at bogen henvendte sig til flere forskellige grupper af læsere. Sønderjyllands historie kunne ikke forstås, uden at man redegjorde for arveforhold og lensformer, og "man viger jo ikke tilbage for at beskrive telegrafen og dampmaskinen for lægfolk, skønt det ikke er let.“ Han måtte forbeholde sig sin egen opfattelse, men han erklærede sig villig til at lade den undersøge. "Foreløbig har gehejmeråd Krieger godkendt den form, fortællingerne har $\mathrm{i}$ renskriften, men for mig må hjertelig gerne enhversomhelst anden gå dem efter, og jeg skal med den største glæde modtage enhver oplysning, der kunne bringe mig selv videre i forståelsen af disse forhold“.

Formodentlig er bogen herefter gået til opsæatning, og Steenstrup synes at have giort mange bemærkninger til korrekturen. Et vidnesbyrd herom har man i de mange breve og korte notitser fra Jørgensens hånd, der foreligger $\mathrm{i}$ udvalgets arkiv. Det kom til flere ret skarpe meningsudvekslinger mellem udgiver og forfatter, som ikke her nærmere skal gennemgås, da det vil beslaglægge megen plads, men helt uinteressante er de ikke. Også billedmaterialet og udarbejdelsen af kortene gav anledning til mange bemærkninger, og det ligger klart for dagen, at Jørgensen af og til blev både utålmodig og irriteret. Der kan i denne forbindelse henvises til et trykt brev fra Jørgensen til Steenstrup. ${ }^{34}$ Omsider var man ved vejs ende, og bogen kunne gå til tryk. Da udsendelsen nærmede sig, enedes man om at søge at tilbageholde omtale i pressen af bogens udsendelse. ${ }^{35}$ Man frygtede nemlig, at de preussiske myndigheder skulle skride ind mod bogens udbredelse $i$ Nordslesvig. Der er dog ikke bevaret noget vidnesbyrd om, at en sådan indskriden fandt sted.

Det kunne være fristende på dette sted nærmere at omtale bogens indhold og give nogle prøver på forfatterens personlige engagement i fremstillingen af begivenheder og personer $o g$ af hans uom tvistelige fortællekunst, men det vil føre altfor vidt. Det skal blot siges, at selv om bogen nu er 100 år gammel, vil en moderne læser, selv om fremstillingen på sine steder kan virke lidt gammeldags romantisk, med udbytte kunne gå i gang med læsningen. Kun nogle ganske få prøver vil kunne gives.

Allerede i den første fortælling om Danske kongesagn slås et gennemgående tema an. Bogens hovedformål var jo at fortælle den nordslesvigske ungdom, at de sammen med kongeriget havde oplevet en rig og afvekslende historie, som fuldt ud kunne måle sig med de andre europæiske folks historiske udvikling. Fortællingen indledes således: "Intet andet rige $\mathrm{i}$ vor verdensdel kan i alder måle sig med det danske. I uafbrudt følge går vor 
kongerække tilbage gennem et tusindår, og alt længe før den tid hører vi tale om et samlet og mægtigt kongerige i Danmark «. Sønderjylland og Danmark havde hørt nært sammen i mere end 1000 år, da adskillelsen $i 1864$ fandt sted.

$\mathrm{Og}$ et andet eksempel. Som afslutning på fortællingen om, hvorledes det danske folkeliv vågnede $\mathrm{i}$ årene efter 1830 , hedder det: "Således var i få år kampen begyndt over hele linien. Det var endnu ingen folkebevægelse, men der var slået til lyd, og de første danske toner havde lydt fra Ejderen til Skodborgå. Det var som daggryet til en slagdag, når hæren vækkes, når de første pile hviner gennem luften, og kampråbet begynder at lyde fra mange hold".

Og så de gribende afslutningsord efter skildringen af krigen i 1864. "Guds veje er uransagelige. Den tunge tilskikkelse han sendte det danske folk, har tilvisse $\mathrm{i}$ mange måder været til styrkelse og vækkelse, til inderliggørelse $\mathrm{i}$ kærlighed til fædrelandet, til styrkelse af folkets bløde og svage sind og til udvikling af dets rige åndelige evne. Tiderne skifter, og menneskenes sind forandres; vi kan ikke slippe det håb, at det danske Sønderjyllands skæbne engang vil formildes, at den afgørelse, som mislykkedes 1864 , endnu vil kunne opnås som en endelig afslutning af dette lands omskiftelige historie. Den bør da kunne blive et pant på varig fred og god forståelse mellem de beslægtede folk nord og syd for den nationale grænse, der er sat af århundreders udvikling, og som det ikke er vor sag at gå i rette med «. Der kan vist ikke være nogen tvivl om, at disse manende ord har fundet en dyb medklang i tusinder danske nordslesvigeres hjerter og i høj grad bidraget til at holde genforeningshåbet $i$ live.

Bogens modtagelse er der ingen grund til at gå nærmere ind på. Såvel i Nordslesvig som i kongeriget blev den modtaget med glæde, og talrige er de vidnesbyrd, der foreligger om dens betydning for udbygningen af kendskabet til Sønderjyllands historie og som modvægt mod de nordslesvigske skolers fremadskridende fortyskning. Som eksempel på en moderne læsers reaktion, da han modtog bogen i konfirmationsgave, skal blot henvises til lensgreve Hans Schacks vurdering af bogen i Sprogforeningens Almanak for 1981. Her sættes bogen på linie med den blå sangbog og den sønderjyske salmebog.

Bogens succes kan også illustreres ved de mange nye udgaver, som så dagens lys. Allerede i $1886 \mathrm{kom} 2$. oplag. Sin vane tro havde Jørgensen ladet sit håndeksemplar af 1 . udgaven indbinde med indskudte hvide blade, hvorpå han fra tid til anden indførte forskellige rettelser. Det fremgår bl.a. heraf, at han havde tænkt sig at tilegne 2. udgaven til brygger Jacobsen; men det skete ikke, uvist af hvilken grund. Tilegnelsen lød: „Fædrelandsvennen, brygger J. C. Jacobsen. Dr. phil. R. af D. og DM tilegnet «. Den største ændring i 2. oplag bestod $\mathrm{i}$ en sammenskrivning af fortællingerne 18 og 19 om de 
sønderjyske delinger, formodentlig et par af de for læserne tungeste fortællinger. Fremstillingen blev forkortet og optoges nu som en ny fortælling nr. 18 under titlen: Sønderjyllands delinger. Der blev herefter plads til en ny fortælling nr. 19 omhandlende Tyge Brahe og Arild Hvidtfeld. Denne fortælling var tidligere offentliggjort $i$ "Nytårsgave til danske kvinder “, udg. af L. Fenger i 1883. Endnu et nyt oplag skulle forfatteren opleve. Det udkom i 1892, og oplaget var forøget fra 5 til 7.000. Kort efter forfatterens død udsendtes 4. oplag, og da det var udsolgt, overvejede udvalget, om man i forbindelse med en ny udgave skulle modernisere teksten og bringe den $\mathrm{i}$ overensstemmelse med den historiske videnskabs nyeste resultater. Faktisk var der flere historikere bl.a. Aage Friis, som tilrådede en ændring, navnlig af skildringen af begivenhederne i 1460 og i 1721. Dette blev dog ikke til noget, navnlig efter at Kr. Erslev i et brev af 13. januar 1907 bestemt havde frarådet, at man skrev bogen om. Samme opfattelse havde historikeren Hans Olrik, som i et brev af 25. september 1907 bl.a. udtalte: „De $\mathbf{4 0}$ fortællinger står for mig som et klassisk værk, hvori man ikke bør rette, ligesom man f.eks. ikke ville ændre en tøddel i Holbergs historiske skrifter, hvor meget der end kunne være af »urigtigt « i dem«. Resultatet blev da et uændret optryk i 1907, hvoraf 3000 eksemplarer påny sendtes til uddeling i Nordslesvig. Folkeoplysningsudvalget udsendte i 1915 endnu et oplag, hvor opsætning, indbinding og billedudvalg var moderniseret, men teksten uændret. Da udvalget, repræsenteret af sin daværende formand overbibliotekar Carl S. Petersen på familiens forespørgsel ikke mente længere at kunne påtage sig et nyt oplag, overlod man i 1940 De unges Forlag at udsende en ny udgave, og 7. oplag så dagens lys i 1941. Så sent som i december 1981 har Vintens forlag endnu engang optrykt bogen og givet den et fornemt udstyr og en helt moderne opsætning. Den nye udgave har fået helt nye billeder, først og fremmest en lang række farvegengivelser af elskede historiemalerier. Desuden er bogen forsynet med et forord, skrevet af Jørgensens biograf, professor Lorenz Rerup. Blandt billederne er også professor Carl Blochs kendte fremstilling af Christian 2. som fange på Sønderborg slot. Dette billede står side om side med forfatterens beretning om de ret frie forhold, hvorunder Christian 2. henlevede sit fangenskab på slottet ved Alssund. Det er nok tvivlsomt, om forfatteren ville have godkendt en sådan illustrering.

Med 8. oplag er bogen vel udsendt i henved 60.000 eksemplarer, et efter danske forhold usædvanligt oplag for en bog af denne karakter. Professor Olriks karakteristik af værket som en klassiker i dansk historisk litteratur har således aktuel gyldighed. For folkeoplysningsudvalget var bogen dets største succes, og også for familien Jørgensen betød bogen en økonomisk gevinst. 
Takket være brygger Jacobsens rundhåndethed modtog forfatteren for første oplag et honorar på $5.000 \mathrm{kr}$., hvilket svarede til $2 \frac{1}{2}$ års gage som arkivfuldmægtig. I alt modtog familien, indtil sidste udbetaling i 192018.900 kr. i honorarer. Hvad folkeoplysningsudvalget tjente på publikationen er ukendt.

10 år efter, at de 40 fortællinger var udkommet, udsendte forfatteren en ny samling historiske fortællinger, som fik titlen "Fortællinger af Nordens historie«. 1. bind udkom i december $1892 \mathrm{og}$ omhandlede tiden indtil reformationen. Året efter udkom bind 2, der skildrede den nyere tid og førte fremstillingen frem til ca. 1866. Den sidste fortælling skildrede »Tilnærmelserne mellem de nordiske folk og riger $\mathrm{i}$ vort århundrede «, altså en redegørelse for den skandinaviske bevægelse og dens ledere. I alt indeholdt den nye samling 30 fortællinger og udgjorde ca. 715 tryksider. Også dette værk var gennemillustreret og indeholdt forskellige kort og slægttavler.

Fortællingerne var udarbejdet $\mathrm{i}$ årene $1886-90 \mathrm{og}$ var blevet til, fordi mange læsere af de 40 fortællinger ved forskellige lejligheder havde gjort forfatteren opmærksom på, at der i disse ikke tilstrækkeligt var gjort rede for forholdet mellem Danmark og de andre nordiske lande. Jørgensen var klar over dette forhold, men havde hidtil ikke haft lyst til at foretage ændringer $i$ sit oprindelige værk, selv om han måtte indrømme, at der manglede noget, for at man kunne nå til fuld forståelse af vor egen fortid „og til en nogenlunde tydelig forestilling om mulighederne for vor nationale fremtid ". Han havde derfor besluttet sig til at forfatte den nu foreliggende fremstilling af nabofolkenes egen selvstændige historie og åndelige udviklingsgang.

Det var ikke uden betænkeligheder, at han udsendte sin nye bog. Som aktiv historiker havde han vænnet sig til at bygge på det bevarede originale kildemateriale, og som han skrev i forordet, "kan det næsten blive en overvindelse i så henseende at slå af på fordringerne og fortælle historie på anden og tredje hånd. Kun den glæde jeg selv har følt ved sysselsættelsen med det store emne og ved udformningen af hver enkelt fortælling, har givet mig håb om, at også andre ville kunne have glæde af at dvæle ved de samme billeder og tanker“. Herefter slog han påny et tema an, som han ofte havde brugt, og som åbenbart havde lejret sig dybt $i$ hans følsomme sind. Forordet sluttede nemlig med følgende: "Derimod har jeg ikke noget øjeblik skjult for mig selv, at lærde kaldsfæller vil finde mere at udsætte end at rose ved dette forsøg. Jeg kan da også kun ønske, at andre med mere tid til deres rådighed måtte fả lyst til at tage den samme opgave op; indtil det sker, vil det foreliggende forsøg forhåbentlig kunne bøde på et savn, der synes at være følt i vide kredse

De nordiske fortællinger udsendtes også af folkeoplysningsudvalget. 
Førsteudgaven var trykt i 5.000 eksemplarer, og en 2. udgave udkom efter forfatterens død i årene 1900-01, formodentlig i samme oplag og omtrent samtidig med, at den kendte skolemand og politiker Johan Ottosen påbegyndte udsendelsen af trebindsværket Vor Historie, der ligeledes omfattede de nordiske rigers historiske udvikling, og som også udmærker sig ved en naturlig og smittende fortælleglæde. Selv om de nordiske fortællinger aldrig blev den klassiker $\mathrm{i}$ vor historiske litteratur fra forrige århundrede som de 40 fortællinger, kan man udmærket stadig tage disse ned af boghylden og have fornøjelse ved at læse en eller flere af de med stor kærlighed og ånd skrevne nordiske fortællinger.

\section{NOTER OG HENVISNINGER}

Anvendte forkortelser:

Breve: A. D. Jørgensens breve. Udg. af den danske historiske forening $i$ hundredåret for dens stiftelse. Ved Harald Jørgensen. 1939.

Redegørelsen: A. D. Jørgensen: En redegørelse for min udvikling og mit forfatterskab. 1901.

1. Breve s. $120-21$.

2. Dansk Biografisk Leksikon 3. udg. bd. VII, 1981, s. 513-17 og den der anførte litteratur.

3. Redegørelsen s. 112.

4. I 1910 udkom den første samlede redegørelse for den politiske og nationale udvikling i Nordslesvig, nemlig M. Mackeprangs bog: Nordslesvig 1864-1909. En ny og mere udførlig skildring er optaget i den store $"$ Sønderjyllands historie bd. V, der udkom i $1930^{\circ}$ erne. Se også A. D. Jergensens pjece fra 1880: Den nationale stilling i Nordslesvig i anledning af traktaten af 11. oktober 1878. Den udkom under pseudonymet "En Nordslesviger “.

5. En fuldstændig bibliografi over A. D. Jørgensens forfatterskab er trykt i bind IV af den samlede udgave af A. D. Jorgensens afhandlinger, der offentliggjordes 1898-99. Oversigten findes på s. 511-22.

6. Breve s. 15-22.

7. Breve s. 22.

8. Til belysning af Jørgensens historiske forfatterskab $i$ denne periode findes en rakke værdifulde oplysninger i Redegørelsen s. 114-46.

9. Breve s. 31-34. I brevudgaven findes adskillige breve til Rordam, der mere eller mindre handler om kirkehistorien. Se brevskriverlisten s. XVII.

10. Breve s. 30-31.

11. Breve s. 67.

12. Redegørelsen s. 139.

13. Redegørelsen s. 140-41.

14. Breve s. $64-66,67-70,74-75$ og 86 .

15. Breve s. 68.

16. Anf. sted s. 135.

17. Anf. skrift s. $45-46$.

18. Anf. skrift s. 137.

19. Redegørelsen s. 136-37.

20. Breve s. 96-98.

21. Breve s. 101 . 
22. Om samarbejdet med Bille se Redegørelsen s. 142-43. Se også Breve s. 99-100.

23. Anf. skrift s. 4.

24. Anf. skrift s. 38.

25. Anf. skrift s. $38-39$.

26. Anf. skrift s. 39 .

27. Anf. skrift s. 40 .

28. Breve s. 94.

29. Redegørelsen s. 143-44.

30. I det kgl. biblioteks håndskriftsamling opbevares arkivet fra "Udvalget for folkeoplysnings fremme «. I dette arkiv findes 3 kapsler indeholdende korrespondance- og regnskabssager vedr. udgivelsen af " 40 fortællinger " og "Fortællinger af Nordens historie." De i det flg. citerede breve m.m. findes, hvor intet andet er bemarket, i denne samling.

31. Af de her nævnte bestyrelsesmedlemmer synes Jorgensen kun at have kendt Termansen. Se Redegørelsen s. 133-34.

32. Dette brev er ikke medtaget $\mathrm{i}$ den trykte brevsamling.

33. Breve s. 107-09.

34. Breve s. 114-16.

35. Breve s. 119. 